\title{
Identification of Sulfate- and Arsenate-Reducing Bacteria in Sheep Manure as Permeable Reactive Materials after Arsenic Immobilization in Groundwater
}

\author{
Wahyu Wilopo*, Keiko Sasaki and Tsuyoshi Hirajima \\ Department of Earth Resources Engineering, Faculty of Engineering, Kyushu University, Fukuoka 819-0395, Japan
}

\begin{abstract}
Permeable reactive barriers (PRBs) column tests were performed to investigate the contribution of anaerobic microbial community in sheep manure on the removal of As from groundwater. The column was packed with zero valent iron (ZVI), sheep manure, compost, wood chips, glass beads and gravels. All materials were sterilized except for sheep manure that contains anaerobic bacteria. Decrease in sulfate concentration was observed at the maximum rate of $0.26 \mathrm{mmol} \mathrm{dm}^{-3} \mathrm{day}^{-1}$. In addition, the sulfur isotopic ratio of $\delta^{34} \mathrm{~S}$ increased from the influent $(-4.3 \%$ ) to the effluent $(0.2 \%$ o), suggesting that there was sulfate-reducing activity in the microbial community. Arsenate was more effectively immobilized on ZVI than arsenite. Bacterial community analysis using polymerase chain reaction-denaturing gradient gel electrophoresis (PCR-DGGE) on 16S rRNA sequences suggested that majorities of bacteria were several Clostridium species and one species of Proteobacteria, Geobacter metallireducens GS-15, independently of PRBs column heights. Some of them might have contributed to the removal of arsenic. [doi:10.2320/matertrans.M-MRA2008826]
\end{abstract}

(Received May 21, 2008; Accepted July 22, 2008; Published September 10, 2008)

Keywords: arsenic, immobilization, sheep manure, sulfate-reducing bacteria, zero valence iron

\section{Introduction}

Cost-effective, low maintenance and long-term approaches for removal of heavy metals are greatly desired, therefore permeable reactive barriers (PRBs) as in-situ and passive treatment of groundwater have emerged technologies with great promise. ${ }^{1)}$ The PRBs, which are placed underground in the path of the contaminated groundwater flow and contains reactive materials, have been already established in 1995 in North America. Principles for removing contaminants with a PRBs are based on sorption, precipitation, chemical reduction, and biologically mediated decomposition. ${ }^{2)}$ According to the USEPA (2002) status report, there are 42 full scale installations and 20 pilot scale installations of PRBs for removal organic and non organic contaminants in the United States, Canada and Europe. ${ }^{3)}$

The most commonly used technologies for arsenic immobilization include oxidation-precipitation, coagulation/coprecipitation, sorption and ion-exchange, membrane technologies, foam floatation, solvent extraction and bioremediation. ${ }^{4,5)}$ In the recent years, bioremediation has been paid significant attention because less costs compared to chemical treatment processes and less disturbing to the environment. However, in case of high concentrations of contaminants, it is necessary to combine with chemical reactions to achieve the acceptable rate of processes and better results because some of bacteria can not sustain under high concentrations of contaminant. A variety of organic substrates have been investigated to provide a long terms carbon sources and energy to sustain bacteria, however, no research concerning to genetic analysis of the bacteria included in the materials itself. $^{6-8)}$ Therefore, in this research sheep manure was used as a reactive material due to high population of anaerobic bacteria. ${ }^{9)}$ In addition, sheep manure has a low lignin content, high degradability and capacity to stimulate bacterial activity. ${ }^{10)}$

*Corresponding author, E-mail: wwilopo@mine.kyushu-u.ac.jp
The purpose of this study is to determine anaerobic bacteria in the sheep manure that contribute in the arsenic removal in PRBs. To obtain better understanding, molecular microbiology techniques such as polymerase chain reaction (PCR) and denaturing gradient gel electrophoresis (DGGE) were used to investigate the microbial community in the PRBs column. The present results would provide insights of sheep manure as one of alternative for PRBs materials in the term of bioremediation.

\section{Experimental}

\subsection{Chemical composition of influent solution}

The influent solution was artificially prepared by simulation of As contaminated groundwater with $1.27 \mathrm{mg} \mathrm{dm}^{-3}$ in Sumbawa island, Indonesia and spiked to around $50 \mathrm{mg} \mathrm{dm}^{-3}$ of arsenic. ${ }^{11)}$ The simulated groundwater was prepared as follows (in gram per 1 liter of deionized water): $\mathrm{CaCO}_{3}$ (0.069), $\mathrm{MgCO}_{3}$ (0.065), $\mathrm{KNO}_{3}$ (0.001), $\mathrm{MnSO}_{4} \cdot 5 \mathrm{H}_{2} \mathrm{O}$ (0.263), $\mathrm{KAsO}_{2}$ (0.058) and $\mathrm{KH}_{2} \mathrm{AsO}_{4}$ (0.048). The $\mathrm{pH}$ was adjusted to $6.25 \pm 0.25$ with $1 \mathrm{~mol} \mathrm{dm}^{-3} \mathrm{HCl}$ and $1 \mathrm{~mol} \mathrm{dm}^{-3} \mathrm{NaOH}$. The solution was purged with nitrogen gas for $2 \mathrm{~h}$ to minimize the content of dissolved oxygen and kept under anaerobic conditions prior to use.

\subsection{Experimental method}

The PRB column tests were performed using acrylic cylindrical column with $40 \mathrm{~cm}$ in height, $7.5 \mathrm{~cm}$ in inner diameter, 10 side ports along the vertical direction, and approximately $1767.86 \mathrm{~cm}^{3}$ in internal volume. The bottom layer $(1.5 \mathrm{~cm})$ and top layer $(1.5 \mathrm{~cm})$ of the column packing consisted of $100 \%$ glass beads $(0.6-0.8 \mathrm{~mm}$ in diameter) as non reactive material. The middle reactive layer was composed of 5(v/v)\% ZVI, 23(v/v)\% compost, 22(v/v)\% woodchips, $30(\mathrm{v} / \mathrm{v}) \%$ glass beads, $20(\mathrm{v} / \mathrm{v}) \%$ gravels and $2(\mathrm{v} / \mathrm{v}) \%$ sheep manure. ZVI is well known as good sorbents for arsenate and arsenite. ${ }^{12,13)}$ Two kinds of organic materials compost and wood chips were used as carbon sources for 
Table 1 Primers used for PCR amplification in this study.

\begin{tabular}{|c|c|c|c|}
\hline Primer & Sequence $\left(5^{\prime}-3^{\prime}\right)$ & Target & Reference \\
\hline $27 \mathrm{f}$ & AGAGTTTGATCCTGGCTCAG & Bacterial 16S rDNA & Edwards et al. $(1989)^{16)}$ \\
\hline $1523 r$ & AAAGGAGGTGATCCAGCC & Bacterial 16S rDNA & Edwards et al. $(1989)^{16)}$ \\
\hline $341 \mathrm{f}$ & CCTACGGGAGGCAGCAG & Bacterial 16S rDNA & Muyzer et al. $(1993)^{17)}$ \\
\hline $518 \mathrm{r}$ & ATT ACC GCG GCT GCTGG & Bacterial 16S rDNA & Neefs et al. $(1990)^{18)}$ \\
\hline $341 f-G C$ & $\begin{array}{l}\text { CGCCCGCCGCGCGCGGCGGG } \\
\text { CGGGGCGGGGGCACGGGGG } \\
\text { GCCTACGGGAGGCAGCAG }\end{array}$ & Bacterial 16S rDNA & Muyzer et al. $(1993)^{17)}$ \\
\hline
\end{tabular}

microorganisms. Sheep manure was added to provide a variety of anaerobic microorganisms. ${ }^{9)}$ The manure used in this study was taken from livestock in Mitsuse, Saga Prefecture, Japan, a few days before use. Compost $(\phi 0.1-$ $0.5 \mathrm{~cm})$ and wood chips $(\phi 0.05-0.25 \mathrm{~cm})$ were provided by a local company. Glass beads and gravels were used to maintain the permeability of the column. All materials were sterilized by autoclaving, except for the sheep manure. Then, all materials were mixed homogeneously, filled uniformly in the columns, and nitrogen gas with pressure $0.3 \mathrm{MPa}$ was purged for $12 \mathrm{~h}$ to generate anaerobic conditions. To activate microorganisms such as sulfate-reducing bacteria (SRB), $1.5 \mathrm{dm}^{3}$ of $1000 \mathrm{mg} \mathrm{dm}^{-3} \mathrm{Na}_{2} \mathrm{SO}_{4}$ and $5 \%$ sodium lactate solution was introduced from the bottom of column. The flow rate of influent was initially set at $0.21 \mathrm{~cm} \mathrm{~h}^{-1}$ from the bottom to the top by peristaltic pumps (EYELA 10413787, Rikakikai Co. Ltd., Japan), resulting in 2.77 days of residence time. All experiments were conducted in an anaerobic glove box (COY; Michigan, USA) purged with a $95 \% \mathrm{~N}_{2}: 5 \% \mathrm{H}_{2}$ gas mixture. Effluent solutions were regularly collected twice a week, while 36 times of pore volume (pv) of influent solutions travels. Pore volume (pv) is defined as the required time to travel for the influent from the bottom to the top of the column and used as a time unit. At pv 36 the side-port samples were taken from the column before decomposing of PRBs materials.

\subsection{Procedure for analysis}

Temperature, $\mathrm{pH}$, redox potential, and alkalinity were measured immediately after sample collection. Temperature and $\mathrm{pH}$ were measured using TOA WM-22EP GST-2729C electrodes, the redox potential was determined using TOA RM-20P PST-2739C electrodes and converted to $E h$ vs NHE. Alkalinity was determined using a $\mathrm{Hach}^{\mathrm{TM}}$ digital titrator with $0.1 \mathrm{~N} \quad \mathrm{H}_{2} \mathrm{SO}_{4}$ (Titration Method 2320B; American Public Health Association (APHA), 1992). Total organic content (TOC) was measured by TOC-5000A (SHIMADZU). Sulfur isotopic compositions were measured using a continuous flow-isotope ratio mass spectrometer (IsoPrime ${ }^{\mathrm{TM}} \mathrm{EA}, \mathrm{GV}$ Instruments, UK) and were reported in the conventional $\delta^{34} \mathrm{~S}$ notation relative to Vienna Cañyon Diablo Troilite. The overall reproducibility of the sulfur isotopic analysis was $\pm 0.2 \%$. Sulfate concentrations were determined using a Dionex DX-120 ion chromatograph. Total As was determined by hydride generation/atomic absorption spectrometry (HG-AAS) after decomposition of organic matters according to JIS K 0102. For determination of arsenite (As(III)), sample solution was adjusted to $\mathrm{pH} 9$.
In the same manner as in JIS K0102, HG-AAS was applied without KI. The details are described in Tuji et al. ${ }^{14)}$ Arsenate $(\mathrm{As}(\mathrm{V}))$ was determined by subtracting the value of arsenite from the total of arsenic. After taking side ports samples at pv 36 and numbered from the bottom to the top of the column (L10 to L1), the column materials were also taken by decomposing the column under anaerobic condition. Residual materials in a reactive zone were divided into 10 fractions along the water traveling direction as follows: $\mathrm{S} 10(1.5-5.2 \mathrm{~cm}), \mathrm{S} 9(5.2-8.9 \mathrm{~cm}), \mathrm{S} 8(8.9-$ $12.6 \mathrm{~cm}), \mathrm{S} 7(12.6-16.3 \mathrm{~cm}), \mathrm{S} 6(16.3-20 \mathrm{~cm}), \mathrm{S} 5(20-$ $23.7 \mathrm{~cm}), \mathrm{S} 4(23.7-27.4 \mathrm{~cm}), \mathrm{S} 3(27.4-31.1 \mathrm{~cm}), \mathrm{S} 2(31.1-$ $34.5) \mathrm{cm}$ and $\mathrm{S} 1(34.8-38.5 \mathrm{~cm})$ from the bottom of the column. The residual ZVI granules were separated using a magnet covered with a plastic bag from PRB materials in an anaerobic glove box, to provide for X-ray fluorescence (XRF; RIX-3100, Rigaku).

\subsection{Most probable number method}

The most probable number (MPN) method was performed to enumerate the population of SRB in solid samples from fractions S10, S8, S5, S2 and S1. SRB medium solution was prepared according to Potgate (1963), ${ }^{15)}$ that is (in grams per $2 \mathrm{dm}^{3}$ ): $\mathrm{KH}_{2} \mathrm{PO}_{4}(0.5), \mathrm{NH}_{4} \mathrm{Cl}$ (1), $\mathrm{Na}_{2} \mathrm{SO}_{4}$ (4.5), $\mathrm{CaCl}_{2} \cdot 2 \mathrm{H}_{2} \mathrm{O}(0.4), \mathrm{MgSO}_{4} \cdot 7 \mathrm{H}_{2} \mathrm{O}(0.06)$, Na-lactate (2.502), Na-acetate (1.28), yeast extract (1.0), and Na-citrate (0.3) at $\mathrm{pH}$ 7. One gram of solid sample from each fraction was added to anaerobic culture tubes containing $9 \mathrm{ml}$ of the medium. Iron nails were further added to supply $\mathrm{Fe}^{2+}$ ions in the medium. After 4 weeks incubation in an anaerobic box, the result was read.

\subsection{DNA analysis}

DNA was extracted from solid and liquid samples in the column after 36 pv using a DNA isolation kit from MO BIO Laboratories Inc. One gram of PRBs materials and $0.1 \mathrm{dm}^{3}$ of solution after decomposing the column were used to extract DNA, respectively. Extracted DNA was first amplified by polymerase chain reaction (PCR), and then subjected to denaturing gradient gel electrophoresis (DGGE). The primers used for PCR are shown in Table 1. Universal PCR primers were used in the amplification of DNA enable DGGE to resolve a wide range of microbial diversity in a given microbial ecosystem without the constraints of specific media or the laborious sequencing of clone libraries. First PCR amplification used $27 \mathrm{f}$ and $1523 \mathrm{r}$ primers to construct $16 \mathrm{~S}$ rRNA gen a library was performed in a total of $50 \mu \mathrm{dm}^{3}$ of mixture PCR. ${ }^{16)}$ Each PCR mixture contained $5 \mu \mathrm{dm}^{3}$ 
template DNA, $25 \mu \mathrm{dm}^{3}$ Premix $\mathrm{Taq}^{\mathrm{TM}}$ reaction buffer, $1 \mu \mathrm{dm}^{3}$ forward primer, $1 \mu \mathrm{dm}^{3}$ reverse primer, and $18 \mu \mathrm{dm}^{3}$ sterilized water. The premix Taq buffer and primers used from Takara Bio Inc. (Japan). Thermal cycling was carried out with an initial denaturation step of $94^{\circ} \mathrm{C}$ for $10 \mathrm{~min}$, followed by 30 cycles of denaturation at $94^{\circ} \mathrm{C}$ for $1 \mathrm{~min}$, annealing at $52^{\circ} \mathrm{C}$ for $2 \mathrm{~min}$, elongation at $72^{\circ} \mathrm{C}$ for $2 \mathrm{~min}$ and extension at $72^{\circ} \mathrm{C}$ for $7 \mathrm{~min}$. The integrity of the total DNA was checked by agarose gel electrophoresis and ethidium bromide staining, and DNA concentration was estimated using molecular weight standards (DNA Ladder, BIONEER). Second PCR amplification was conducted for DGGE analyses using $5 \mu \mathrm{dm}^{3}$ of the template from first PCR using primers $341 \mathrm{fGC}$ and $518 \mathrm{r}$ with $50 \mu \mathrm{dm}^{3}$ of mixture in the same manner as the first PCR, generating $16 \mathrm{~S}$ rDNA fragments corresponding to nucleotide positions $341-$ 534 of the E. coli sequence. ${ }^{17,18)}$ The thermal profile for amplification was as follow: an initial denaturation step of $94^{\circ} \mathrm{C}$ for $10 \mathrm{~min}$, followed by 30 cycles of denaturation at $94^{\circ} \mathrm{C}$ for $0.5 \mathrm{~min}$, annealing at $55^{\circ} \mathrm{C}$ for $1 \mathrm{~min}$, elongation at $72^{\circ} \mathrm{C}$ for $1 \mathrm{~min}$ and extension at $72^{\circ} \mathrm{C}$ for $7 \mathrm{~min}$. PCR products showing the correct molecular weight and sufficiently high concentration were subsequently analyzed by DGGE as described by Muyzer et al. ${ }^{17)}$ PCR products were re-concentrated using $3 \mathrm{~mol} \mathrm{\textrm {dm } ^ { - 3 }}$ sodium acetate and ethanol $(99.5 \%$ and $70 \%)$. The re-concentrated DNA fragments were applied to an $8 \%(\mathrm{w} / \mathrm{v})$ polyacrylamide gel containing a linear gradient ranging from $30 \%$ to $70 \%$ of denaturant ( $7 \mathrm{~mol} \mathrm{dm}^{-3}$ urea and $40 \%$ formamide). Gel electrophoresis was performed at 175 volt for $16 \mathrm{~h}$ in $1 \times$ TAE buffer (0.04 mol dm ${ }^{-3}$ Tris-acetate, $1 \mathrm{mmol} \mathrm{dm}^{-3}$ EDTA, $\left.\mathrm{pH} 8.5\right)$ at a constant temperature of $60^{\circ} \mathrm{C}$. After the electrophoresis, the gel was stained with ethidium bromide solution and photographed with a Fluor-S MultiImager (Bio-Rad). To determine the gene sequences corresponding to the DGGE bands, the bands from the DGGE fingerprints were cloned and sequenced. A second DGGE was necessary to confirm that the band from the first DGGE contained a single species of DNA. Excised bands were dissolved in $50 \mu \mathrm{dm}^{3}$ of Tris EDTA buffer solution pH 8.0 (Biochemika, Fluka, Germany) and shaken overnight at room temperature. Then the dissolved DNA was amplified again by PCR using primers $341 \mathrm{f}$ and $518 \mathrm{r}$. The PCR products were reconcentrated using $3 \mathrm{~mol} \mathrm{dm}^{-3}$ sodium acetate and ethanol (99.5\% and 70\%). The concentrated DNA was purified using the Qiaex II gel extraction kit (Qiagen). Pure DNA was examined by PCR for the presence of the appropriate insert using the $341 \mathrm{f}$ or $518 \mathrm{r}$ primer. DNA containing the inserts was cloned, and inserts showing different DGGE patterns were sequenced using the $\mathrm{CEQ}^{\mathrm{TM}} 8000$ Genetic Analyzer (Beckman Coulter). Clone sequences were entered into the program BLASTN 2.2.4 ${ }^{19)}$ to identify similar sequences in known bacterial genomes.

\section{Results and Discussion}

Changes in $\mathrm{pH}$, total organic carbon (TOC), alkalinity, temperature, $\mathrm{SO}_{4}{ }^{2-}$ and $\mathrm{As}$ concentrations with $\mathrm{pv}$ are presented in Fig. 1 and Fig. 2. Initially, pH increased from 6.25 in the influent to around 7 in the effluent, then decreased after pv 33. Dissolution of the ZVI caused a $\mathrm{pH}$ increase in the effluent as follows:

$$
\begin{aligned}
2 \mathrm{Fe}^{0}+2 \mathrm{H}_{2} \mathrm{O}+\mathrm{O}_{2} & \rightleftarrows 2 \mathrm{Fe}^{2+}+4 \mathrm{OH}^{-} \\
\mathrm{Fe}^{0}+2 \mathrm{H}^{+} & \rightleftarrows \mathrm{Fe}^{2+}+\mathrm{H}_{2}
\end{aligned}
$$

Eh decreased throughout the experiment from $420 \mathrm{mV}$ in the influent to $-100 \mathrm{mV}$ in the effluent, indicating that reduction occurred. TOC was initially high until pv 25 , after then slightly decreased (Fig. 1(b)). High TOC in the initial phase was probably caused by remaining sodium lactate, which was loaded before the experiment. Alkalinity in the effluent was higher than in the influent, but after pv 25, these values suddenly decreased to become nearly equal to that of the influent (Fig. 1(c)). The alkalinity decrease was probably caused by a decrease in the amount of bicarbonate, which was produced by SRB respiration of organic carbon:

$$
\begin{gathered}
\mathrm{SO}_{4}{ }^{2-}+2 \mathrm{CH}_{2} \mathrm{O} \stackrel{\mathrm{SRB}}{\rightleftarrows} \mathrm{H}_{2} \mathrm{~S}+2 \mathrm{HCO}_{3}{ }^{-} \\
\mathrm{H}_{2} \mathrm{~S}+\mathrm{M}^{2+} \rightleftarrows \mathrm{MS}(\mathrm{s})+2 \mathrm{H}^{+}, \\
\left(\mathrm{M}^{2+} \text { is a divalent metallic ion. }\right)
\end{gathered}
$$

The formation of bicarbonate indicates the ability of SRB to control the $\mathrm{pH}$ and alkalinity in the column (Figs. 1(a), (c)). Temperature decreased slightly during the experiment from 26 to $22^{\circ} \mathrm{C}$, due to seasonal change from summer to winter when the experiment was conducted (Fig. 1(d)).

Figure 2(a) shows the variation in sulfate concentration with pv. Sulfate concentration in the effluent decreased in comparison with in the influent. The sulfur isotopic ratio of the solution samples at pv 33 showed that $\delta^{34} \mathrm{~S}$ were $-4.3 \%$ and $+0.2 \%$ in the influent and effluent, respectively. Detmers et al. reported that SRB prefers to consume lighter sulfate $\left({ }^{32} \mathrm{~S}\right)$, resulting in a relative increase of $\left.\delta^{34} \mathrm{~S} .{ }^{20}\right)$ Therefore, the decrease of sulfate concentrations and increase in the $\delta^{34} \mathrm{~S}$ value in the effluent indicated that SRB actively worked in the column. The maximum removal rate of sulfate concentration was estimated $0.26 \mathrm{mmol} \mathrm{dm}^{-3}$ day $^{-1}$ at $\mathrm{pv} 12$. Then, the rate of sulfate removal was relatively stable around $0.2 \mathrm{mmol} \mathrm{dm}^{-3}$ day $^{-1}$ until pv 25 , then gradually decreased, indicating decline of SRB activity.

Figure 2(b) shows arsenic removal with pv. Arsenic was successfully immobilized under maximum concentration limit (MCL) until pv 14.7. The total amount of arsenic accumulated was estimated $1296.71 \mathrm{mg}$, corresponding to $94 \%$ removal of As. The mechanism of As removal was mainly by adsorption, precipitation and/or co-precipitation $\mathrm{Fe}$ (III)-bearing minerals as corroded layers on the surface of ZVI. ${ }^{11,12)}$ Relationship of As(III) removal and As(V) removal against $\mathrm{SO}_{4}{ }^{2-}$ removal is depicted in Fig. 3. It was observed that there are positive relations with low linearity. This indicates there might be a few contribution of microorganism on removal of $\mathrm{As}(\mathrm{III})$ and $\mathrm{As}(\mathrm{V})$, although chemical processes are predominant as the above. The hydrogen sulfide generated during the reduction of sulfate by SRB will react with metals, forming insoluble metal sulfide precipitates as shown in eqs. (3) and (4). This may be reflected either the precipitation of As as arsenic sulfides, such as $\mathrm{As}_{2} \mathrm{~S}_{3}$, and/or the incorporation of As into Fe-sulfides, followed by re-dissolution or de-sorption of the As to form 

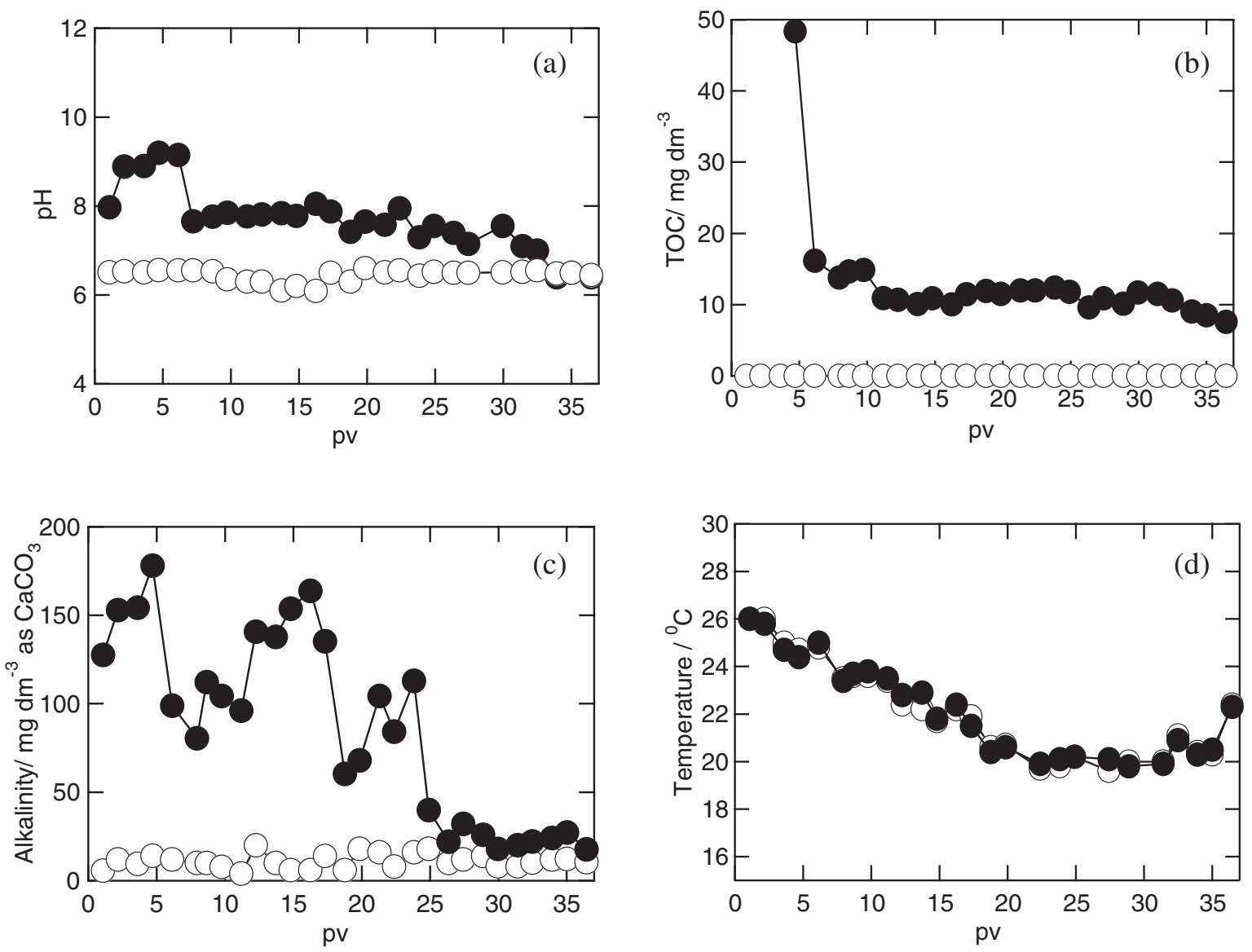

Fig. 1 Changes of (a) pH, (b) TOC, (c) alkalinity and (d) temperature in the influent and effluent with pv. Open and solid symbols indicate influent and effluent, respectively.
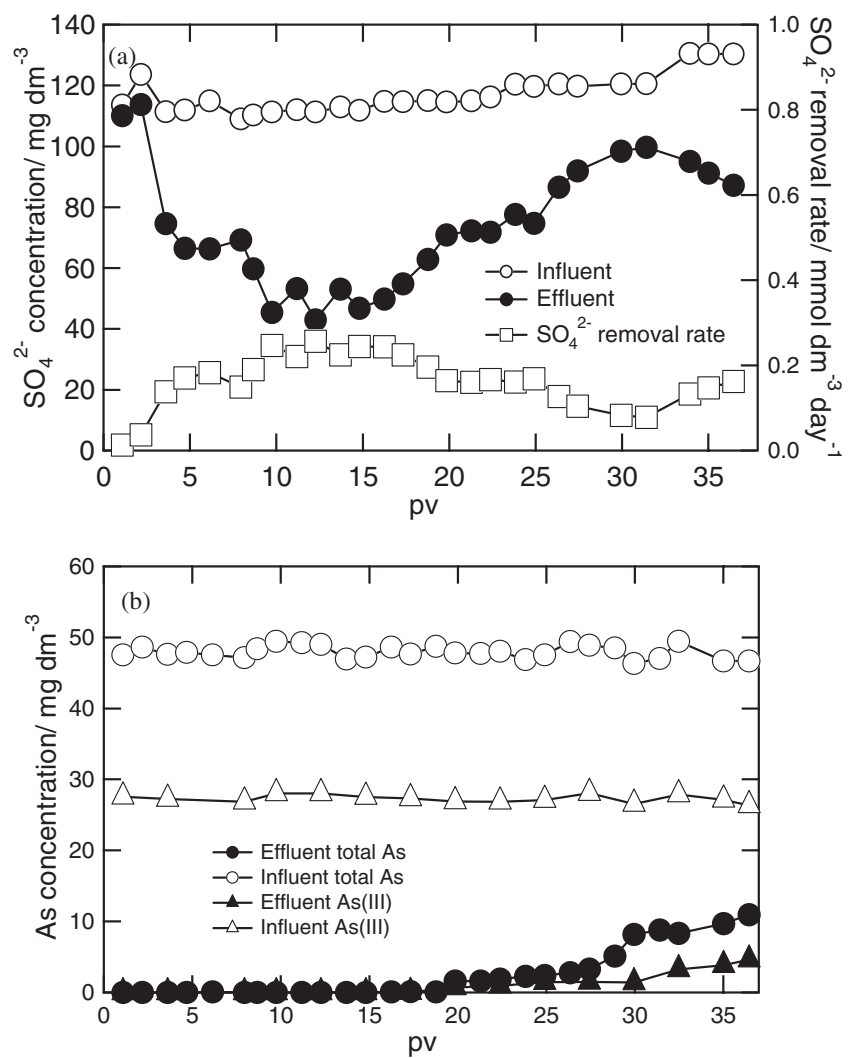

Fig. 2 Changes of sulfate (a) and total As (b) concentrations in the influent and effluent with pv.

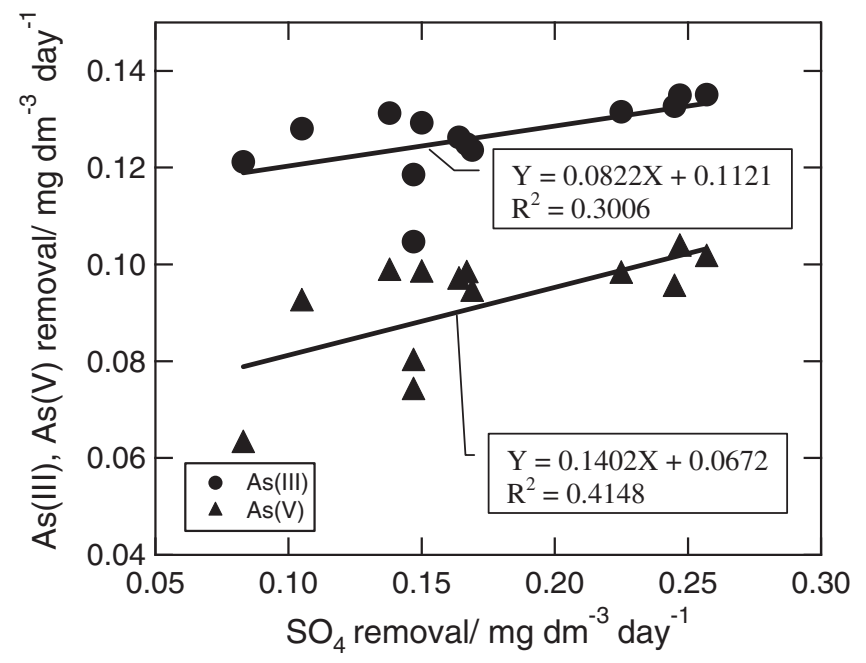

Fig. 3 Correlation between total $\mathrm{As}(\mathrm{III}), \mathrm{As}(\mathrm{V})$ with $\mathrm{SO}_{4}{ }^{2-}$ removal.

soluble thioarsenite (As(III)) complexes. Rittle et al. have found that some of the arsenic was precipitated as an $\mathrm{Fe}-\mathrm{As}-\mathrm{S}$ solid phase by actively sulfidogenic microcosms. ${ }^{21)}$ High alkalinity until pv 25 (Fig. 1(c)) resulting from SRB activity as shown in eq. (3) probably lead a precipitation of carbonate minerals. Therefore, some of As was also probably coprecipitated with carbonate minerals. ${ }^{22)}$

After pv 25, removal of As became less efficient because of decrease in ZVI capacity as well as in SRB activity. 


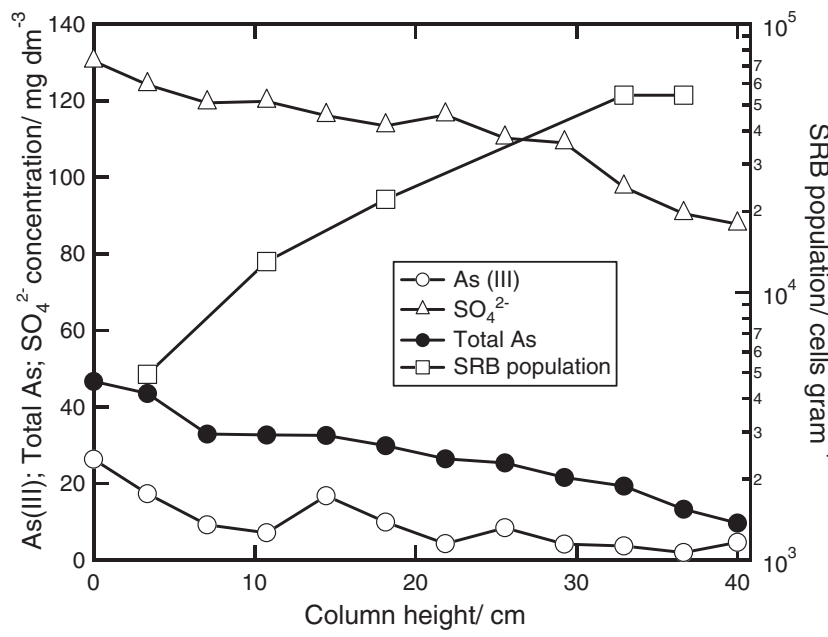

Fig. 4 Vertical profiles of total As (๑), As(III) (○), $\mathrm{SO}_{4}{ }^{2-}(\triangle)$ concentrations and SRB population $(\square)$ evaluated by MPN method at pv 36.

Increase of arsenic concentrations in the column is thought to be the main factor inhibiting SRB growth. Dowdle et al. reported that there are not any sulfate reduction by SRB in the solution containing 600 to $750 \mathrm{mg} \mathrm{dm}^{-3}$ of $\mathrm{As}(\mathrm{V})$ and As(III). ${ }^{23)}$ Rittle et al. have observed reduction of sulfate by SRB with sulfate removal rate was $4.56 \mathrm{mg} \mathrm{dm}^{-3}$ day $^{-1}$ in the presence of $99.5 \mathrm{mg} \mathrm{dm}^{-3} \mathrm{As}$ (III) using lactate and pyruvate $\left(0.5 \mathrm{mmol} \mathrm{dm}^{-3}\right.$ each $)$ as exogenous carbon sources in the batch tests. ${ }^{21)}$ The sulfate removal rate was higher than in this study, probably caused by higher SRB activity due to enough carbon sources. Therefore, decrease of SRB activity in the column was also caused by nutrient supply and could not keep up with metabolic demand, leading to a reduction in TOC (Fig. 1(b)). These studies suggest that SRB activity is strongly influenced by the composition of solution that serves as the SRB medium. Other reason is probably caused by decreased of temperature during experiment as shown in Fig. 1(d). Stein et al. reported that in winter season, the SRB contribution decreased to approximately $25 \%$ in the sulfate removal due to decrease in temperature in the unplanted area. ${ }^{24)}$

The vertical profiles of total As, As(III), sulfate and SRB population at pv 36 is illustrated in Fig. 4. The MPN results showed that the population increased from $5 \times 10^{4}$ cells gram $^{-1}$ at the bottom of the column to $6 \times 10^{5}$ cells gram $^{-1}$ at the top of the column. The greatest decrease in the concentration of total As and sulfate occurred in the upper part of the column, further supporting the notion that both processes are due to the contribution of SRB activity. Vertical profile of As(III) in upper part of the column shows increase the concentration, therefore reduction of total arsenic was mainly dominated with $\mathrm{As}(\mathrm{V})$ species. It might be probably caused by the present of arsenate-reducing bacteria in the column. ${ }^{25)}$ In addition, XRF of residual ZVI grains at pv 36 also showed that $S$ and As concentration increased by increase of distance from the point of sample loading (Fig. 5).

The results of PCR-DGGE to identify bacterial subpopulations are presented in Fig. 6. Sequences were determined from 6 bands as representative, and BLAST comparisons

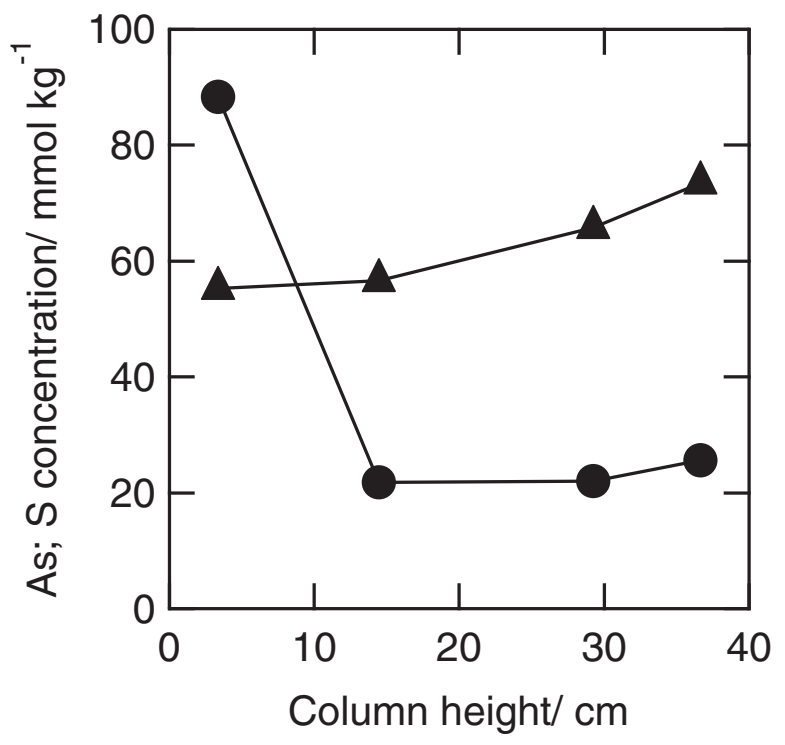

Fig. 5 Vertical profiles of As $(\boldsymbol{O})$ and $\mathrm{S}(\boldsymbol{\Delta})$ contents in solid residues by XRF at pv 36.

with known bacterial sequences revealed that six major species contributed to As removal. The length of the sequences used to calculate each similarity value is shown in Table 2 as an indication of the quality of the species match. The most intense bands in the profiles obtained with both primers sets corresponded to Clostridium kluyveri DSM 555 (band 1), Geobacter metallireducens GS-15 (band 2), Anaerostipes caccae DSM 14662 (band 3), Desulfitobacterium hafniense Y-51 (band 4), Clostridium sp. OhILAS (band 5), and Clostridium difficile 630 (band 6). The detail property of each species was summarized in Table 3.

DGGE profiles show that solid and liquid samples from the upper part are larger variety than in bottom part of the column due to lower As concentration in the top of the column. In addition liquid samples also have more variety species than solid sample. Bands with sequences of Geobacter metallireducens GS-15, Anaerostipes caccae DSM 14662, Desulfitobacterium hafniense $Y-51$ and Clostridium difficile 630 were detected in almost all samples from solid and liquid. Therefore, thus bacteria probably can tolerate high concentrations of As or leading in the competition of nutrient among the species. In contrast, bands with sequence from Clostridium sp. OhILAs and Clostridium kluyveri DSM 555 was found in solid and liquid samples exclusively from the upper part of the inoculated column (S1 and L1). This suggests that those bacteria cannot survive under high concentrations of arsenic, because the upper part of the inoculated column has the lowest As concentration (Fig. 3).

Based on the characteristics of the species identified in the $\mathrm{SRB}$, it is believed that a few are responsible for the decrease in sulfate and $\mathrm{As}(\mathrm{V})$ concentration. One of the responsible species is likely to be Desulfitobacterium hafniense $Y-51$. The genus Desulfitobacterium was originally described as a taxon containing organisms that reduce elemental sulfur and sulfite but not sulfate. ${ }^{26)}$ However, Suyama et al. reported that Desulfitobacterium hafniense $Y-51$ capable of reducing sulfate. ${ }^{27)}$ This bacterial species uses both pyruvate and lactate as electron donors, and it can use metal ions as 
Top Bottom Top Bottom
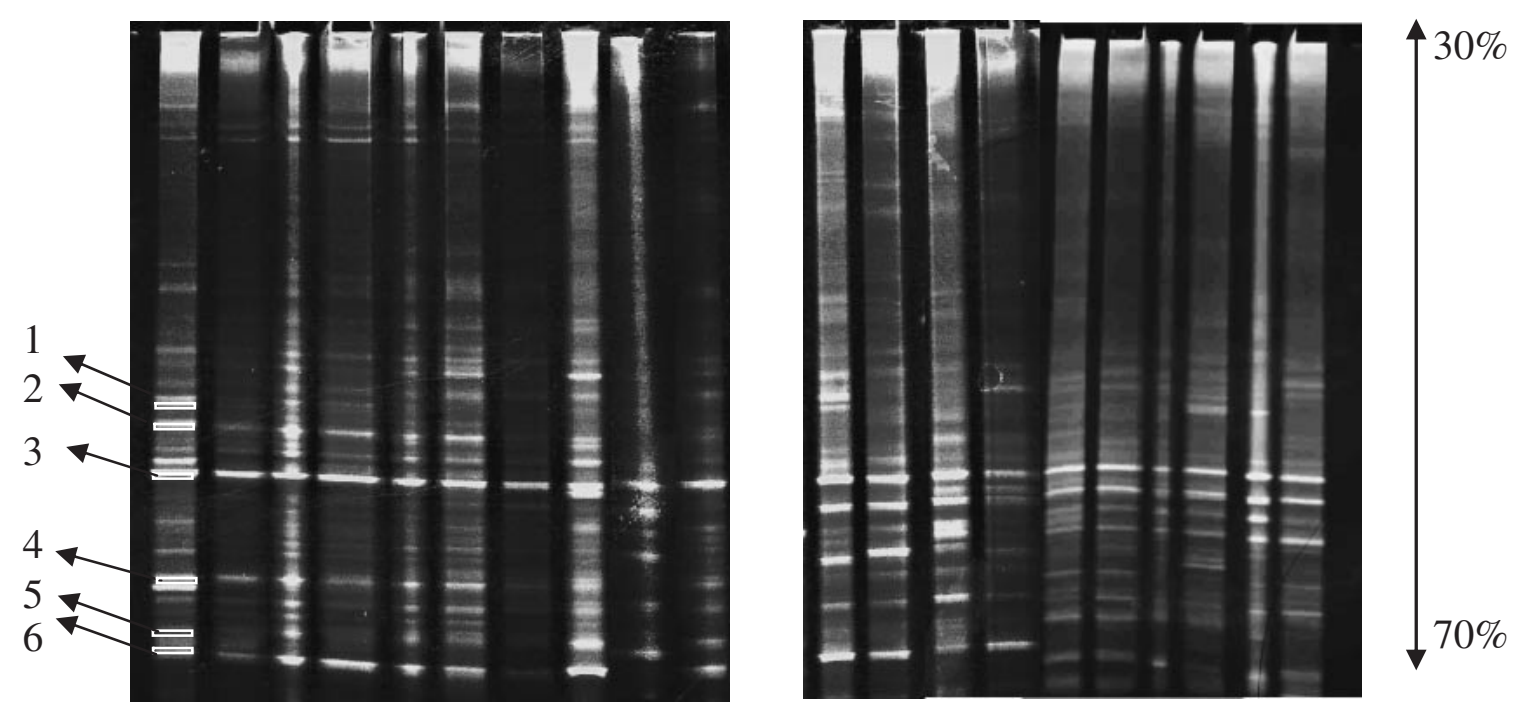

Fig. 6 DGGE profiles for partial $16 \mathrm{~S}$ rRNA gene fragments in solid and aqueous phase in PRB column after pv 36 . The numbers on the left side of the gel indicate S1 bands that were sequenced.

Table 2 Sequence similarities of excised bands that appear in Fig. 5.

\begin{tabular}{|c|c|c|c|c|}
\hline Band & $\begin{array}{l}\text { Most closely related } \\
\text { organism }\end{array}$ & Sequence & $\begin{array}{l}\% \text { sequence } \\
\text { similarity }\end{array}$ & $\begin{array}{l}\text { Taxonomic } \\
\text { class }\end{array}$ \\
\hline \multirow[t]{4}{*}{1} & Clostridium kluyveri DSM & GCCTGATGCAGCAACGCCGCGTGAGTGATGAAGGCCCTCG & 88 & Clostridia \\
\hline & $555($ NC_009706.1) & GGTCGTAAAGCTCTTTGATCAGGGATGATAATGACAGTAC & & \\
\hline & & CTGAAAAACAAGCCACGGCTAACTACGTGCCAGCAGCCGG & & \\
\hline & & CGGTAATA & & \\
\hline \multirow[t]{3}{*}{2} & Geobacter metallireducens & CATCCCTGACAAAGAGCTTTACGACCCGAGGGCCTTCATC & 91 & Deltaproteo- \\
\hline & GS-15 (NC_007517.1) & ACTCACGCGGCGTTGCTGCATCAGAGCTTTCGCCCATTAGT & & bacteria \\
\hline & & AGCAATATTCCCCACTAGCTAGCCTCCCCGTAGAGA & & \\
\hline \multirow[t]{3}{*}{3} & Anaerostipes caccae DSM & GTCATTTNCGTCCCTGCTGATAGAAGCTTTACATACCGAAA & 98 & Clostridia \\
\hline & $14662($ ABAX02000020.1) & GACTTCTTCACTCACGCGGCGTCGCTGCATCAGGGTTTCCC & & \\
\hline & & CCATTGTGCAATATTCCCCACTGCTGCCTCCCGTAGGA & & \\
\hline \multirow[t]{4}{*}{4} & Desulfitobacterium & AAGCAACAGCACGTCAGTCGGTAAGTTGGCATCAGCAATG & 93 & Clostridia \\
\hline & hafniense $Y-51$ & TGACTTGTAACAGGTGATTGGTGAAAGCTCTATTGCGAGTC & & \\
\hline & $\left(N C \_007907.1\right)$ & AGGGGATGATAATGACGGTACCTGACTAAGAAGCCCCGGC & & \\
\hline & & TAACTACGTGCCAGCAGCCGCGGTATACGAAAA & & \\
\hline \multirow[t]{3}{*}{5} & Clostridium sp. OhILAs & CATTATCGTCCCTGAAGACAGAGCTTTACGACCCGAAGGC & 95 & Clostridia \\
\hline & $(N Z A A Q V 01000001.1)$ & CTTCATCACTCACGCGGCGTTGCTGCATCAGGGTTTCNCCC & & \\
\hline & & ATTGTGCAATATTCCCCACTGCTGCCTCCCGTAGGA & & \\
\hline \multirow[t]{3}{*}{6} & Clostridium difficile 630 & GCAACGCCGCGTGAGCGATGAAGGCCTTCGGGTCGTAAAG & 96 & Clostridia \\
\hline & $($ NC_009089.1) & СTCTGTCCTCAAGGAAGATAATGACGGTACTTGAGGAGGA & & \\
\hline & & AGCCCCGGCTAACTACGTGCCAGGCAGCCCGCGGTAAGA & & \\
\hline
\end{tabular}

electron acceptors. It can also grow and reduce $\mathrm{As}(\mathrm{V})$ using lactate as the electron donor. ${ }^{28)}$ In addition, Clostridium sp. OhILAs also respires As(V) and thiosulfate. ${ }^{29)}$ Clostridium sp. OhILAs can tolerate high $\mathrm{As}(\mathrm{V})$ concentrations $\left(>40 \mathrm{mmol} \mathrm{dm}^{-3}\right)$ and they readily degrade the organoarsenical 3-nitro-4-hydroxy benzene arsonic acid (roxarsone) within 48 hours. The results for $\mathrm{As}(\mathrm{V})$ in Fig. 3 might be partly reflected by the presence of that microorganism. Ledbetter, et al. reported the production of copious amounts of $\beta$-realgar, a mineral composed of $\mathrm{As}(\mathrm{III})$ and sulfide in the presence of arsenic-reducing bacteria. ${ }^{30)}$ According to the properties of Desulfitobacterium hafniense $Y-51$ and Clostridium sp. OhILAs as shown in Table 3, those bacteria shown have many similarities that also confirmed with phylogenic tree in Fig. 7. Phylogenic tree was developed using Neighbor-Joining method ${ }^{31)}$ with Mega 4.0. software $^{32)}$ shows those bacteria have close position suggesting another possible case of gene transfer. 
Table 3 The properties of identified species.

\begin{tabular}{|c|c|c|c|}
\hline Band & Species & Properties & References \\
\hline 1 & $\begin{array}{l}\text { Clostridium kluyveri DSM } 555 \\
(\text { NC_009706.1) }\end{array}$ & $\begin{array}{l}\text { Gram-negative; strictly anaerobic; during the growth of the cells fermented } \\
\text { ethanol and acetate to butyrate, caproate and hydrogen gas. }\end{array}$ & Bader, et al. $(1980)^{34)}$ \\
\hline 3 & $\begin{array}{l}\text { Anaerostipes caccae DSM } \\
14662(\text { ABAX02000020.1) }\end{array}$ & $\begin{array}{l}\text { Gram-variable, obligatory anaerobic, catalase negative, asporogenous rod-shaped } \\
\text { cells which produced acetate, butyrate and lactate as the end products of glucose } \\
\text { metabolisms. }\end{array}$ & Schwiertz, et al. $(2002)^{36)}$ \\
\hline 4 & $\begin{array}{l}\text { Desulfitobacterium hafniense } \\
Y-51 \text { (NC_007907.1) }\end{array}$ & $\begin{array}{l}\text { Gram-negative; anaerobic; electron donor: pyruvate, lactate, formate, fumarate, } \\
\text { butyrate; electron acceptor: Elemental S, sulfite, thiosulfite, sulfate, fumarate, } \\
\mathrm{MnO}_{2}, \mathrm{As}(\mathrm{V}), \mathrm{Fe}(\mathrm{III}), \mathrm{Se}(\mathrm{VI}), \text { Nitrate. }\end{array}$ & $\begin{array}{l}\text { Niggemyer, et al. }(2001) ;{ }^{37)} \\
\text { Suyama, et al. }(2001) ;{ }^{25)} \\
\text { Nonaka, et al. }(2006)^{26)}\end{array}$ \\
\hline 5 & $\begin{array}{l}\text { Clostridium sp. OhILAs } \\
\text { (NZ_AAQV01000001.1) }\end{array}$ & $\begin{array}{l}\text { Gram-negative; strictly anaerobic; it can ferment fructose and lactate also respire } \\
\text { arsenate and thiosulfate; tolerate high arsenate concentrations }(>40 \mathrm{mM}) \text { and } \\
\text { readily degrades the organoarsenical roxarsone. }\end{array}$ & $\begin{array}{l}\text { Stolz, et al. }(2006){ }^{23)} \text { Stolz, } \\
\text { et al. }(2007)^{27)}\end{array}$ \\
\hline 6 & $\begin{array}{l}\text { Clostridium difficile } 630 \\
(\text { NC_009089.1) }\end{array}$ & $\begin{array}{l}\text { Gram-positive; anaerobic bacterium; vegetative cells are capable of forming } \\
\text { spores; widely distributed in soil and in the intestinal tracts of animals; cause of } \\
\text { enteric disease in a variety of animal species, including horses, dogs, cats, birds, } \\
\text { rodents, and especially neonatal pigs. }\end{array}$ & Barbut, et al. $(2003)^{38)}$ \\
\hline
\end{tabular}

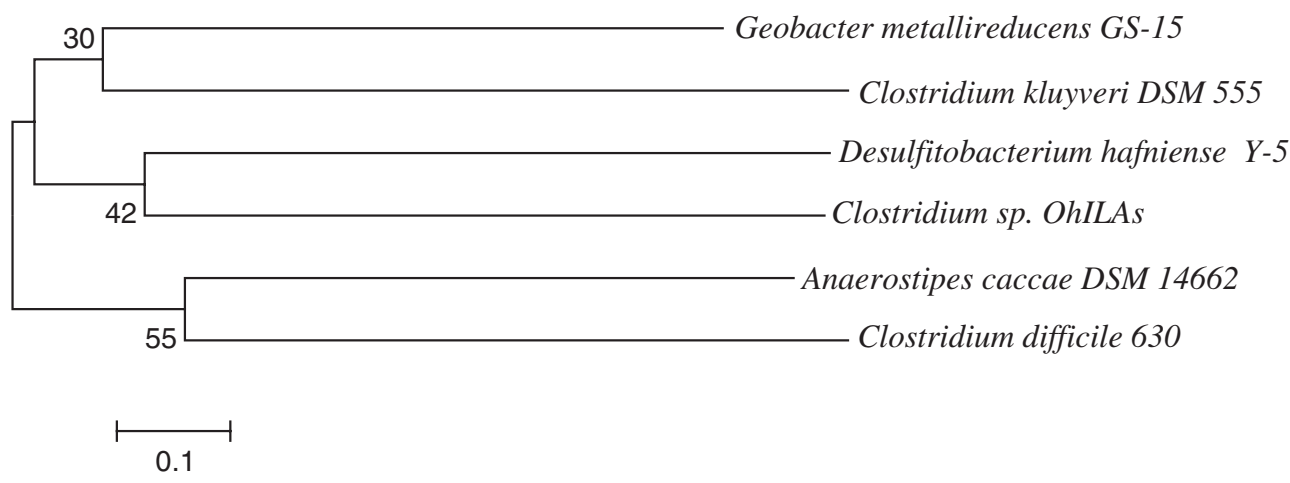

Fig. 7 The 16S rRNA gene-based tree reflecting the phylogenetic positions of the sulfate-reducing bacteria and related bacteria in the present work. The scale bar corresponds to 0.1 estimated nucleotide substitutions per positions. Support for individual nodes is shown as percent values of 500 replications of a bootstrap analysis.

In addition to the Clostridia class, Geobacter metallireducens $G S-15$, which is grouped among delta proteobacteria, can convert sulfate to sulfide. The Geobacter genus is able to colonize habitats with elevated metal concentrations. The analysis of the 16S rRNA sequence of Geobacter metallireducens indicates that its closest known relatives are gramnegative reducers of sulfur and sulfate. It is the first organism known to oxidize organic compounds completely via the reduction of iron and other metals. ${ }^{33)}$

\section{Conclusions}

Arsenic was removed effectively by being immobilized in the ZVI and by being incorporated into precipitates that formed because of bacterial reduction of sulfate. The bacterial species in the PRB were identified by PCR-DGGE on solid and liquid samples after the PRBs had been allowed to accumulate As. The observed reduction in sulfate concentration and increase in $\delta^{34} \mathrm{~S}$ was probably caused by the SRB species Desulfitobacterium hafniense $Y-51$ and Geobacter metallireducens. The arsenate-reducing bacterium
Clostridium sp. OhILAs was also detected. All of these species contributed to remove As from the contaminated sample. PRBs did not remove As effectively after pv 25, and this was due mainly to a decrease in ZVI capacity, and to a reduction of bacterial activity. The bacterial activity probably fell down because of increasing toxicity in the column and nutrient shortages. The results from this experiment suggest that sheep manure can be used as a good alternative PRBs material for the biological remediation of groundwater contaminated with As.

\section{Acknowledgements}

Financial support was provided by Japan Society for the Promotion of Sciences (JSPS 19656239). The authors would like to thank Dr. Y. Sugai at Kyushu University for guiding DNA analysis and Dr. T. Yamanaka at Okayama University for sulfur isotopic analysis. The authors also express gratitude to Dr. K. Fujiwara and Dr. Y. Hattori at Chugai Technos, Co. Ltd for their suggestion and discussion during experiments. 


\section{REFERENCES}

1) D. W. Blowes, C. J. Ptacek, S. G. Benner, C. W. T. McRae and T. A. Bennett: J. Contaminant Hydrol. 45 (2000) 123-137.

2) M. M. Scherer, S. Richter, R. L. Valentine and P. J. J. Alvarez: Critical Reviews in Environmental Science and Technology 30 (2000) 363 411.

3) USEPA, Field Applications of In Situ Remediation Technologies: Reactive barrier, (Washington, DC 20460, 2002).

4) D. Mohan and C. U. Pittman Jr: Journal of Hazardous Materials 142 (2007) $1-53$

5) P. Mondal, C. B. Majumder and B. Mohanty: Journal of Hazardous Materials B137 (2006) 464-479.

6) K. R. Waybrant, D. W. Blowes and C. J. Ptacek: Environ. Sci. Technol. 32 (1998) 1972-1979.

7) I. S. Chang, P. K. Shin and B. H. Kim: Water research 34 (2000) 12671277.

8) I. A. Cocos, G. J. Zagury, B. Clement and R. Samson: Water Research 36 (2002) 167-177.

9) F. Widdel and N. Pfennig: Arch. Microbiol. 129 (1981) 401-402.

10) O. Gilbert, J. de Pablo, J. L. Cortina and C. Ayora: Water Research 38 (2004) 4186-4196.

11) R. S. Oremland and J. F. Stolz: Science 300 (2003) 939-943.

12) S. Bang, G. P. Korfiatis and X. Meng: Journal of Hazardous Materials 121 (2005) 61-67.

13) H. L. Lien and R. T. Wilkin: Chemosphere 53 (2003) 715-725.

14) H. Tuji, Y. Tamari, S. Katagiri, K. Yamazaki and Y. Kusaka: Bunseki Kagaku 40 (1991) 97-100.

15) J. R. Postgate: Appl. Microbiol. 11 (1963) 265-267.

16) U. Edwards, T. Rogall, H. Blocker, M. Emde and E. C. Bottger: Nucleic Acids Research 17 (1989) 7843-7853.

17) G. Muyzer, E. C. De Wall and A. G. Uitterlinden: Applied and Environmental Microbiology 59 (1993) 695-700.

18) J. M. Neefs, Y. Van de Peer, L. Hendriks and R. De Wacther: Nucleic Acids Research 18 (1990) 2237-2317.

19) S. F. Altschul, T. L. Madden, A. A. Schäffer, J. Zhang, Z. Zhang, W Miller and D. J. Lipman: Nucleic Acids Res. 25 (1997) 3389-3402.

20) J. Detmers, V. B. Chert, K. S. Habicht and J. Kuever: Applied and Environmental Microbiology 67 (2001) 888-894.

21) K. A. Rittle, J. I. Drever and P. J. S. Colberg: Geomicrobiology 13 (1995) 1-11.
22) G. Roman-Ross, G. J. Cuello, X. Turrillas, A. Fernandez-Martinez and L. Charlet: Chemical Geology 233 (2006) 328-336.

23) P. R. Dowdle, A. M. Laverman and R. S. Oremland: Appl. Environ. Microbiol. 62 (1996) 1664-1669.

24) O. R. Stein, D. J. Borden-Stweart, P. B. Hook and W. L. Jones: Water Research 41 (2007) 3440-3448.

25) J. F. Stolz, E. Perera, B. Kilonzo, B. Kail, B. Crable, E. Fisher, M. Ranganathan, L. Wormer and P. Basu: Environmental Science and Technology 41 (2007) 818-823.

26) A. Pruden, N. Messner, L. Pereyra, R. E. Hanson, S. R. Hiibel and K. F. Reardon: Water Research 41 (2007) 904-914.

27) A. Suyama, R. Iwakiri, K. Kai, T. Tokunaga, N. Sera and K. Furukawa: Bioscience Biotechnology Biochemistry 65 (2001) 1474-1481.

28) H. Nonaka, G. Keresztes, Y. Shinoda, Y. Ikenaga, M. Abe, K. Naito, K. Inatomi, K. Furukawa, M. Inui and H. Yukawa: Journal of Bacteriology 188 (2006) 2262-2274.

29) J. F. Stolz, P. Basu, J. M. Santini and R. S. Oremland: Annual Reviews Microbiology 60 (2006) 107-130.

30) R. N. Ledbetter, S. A. Connon, A. L. Neal, A. Dohnalkova and T. S. Magnuson: Applied and Environmental Microbiology 73 (2007) 5028-5936.

31) N. Saitou and M. Nei: Molecular Biology and Evolution 4 (1987) 406-425.

32) K. Tamura, J. Dudley, M. Nei and S. Kumar: Molecular Biology and Evolution 24 (2007) 1596-1599.

33) D. R. Lovley, S. J. Giovannoni, D. C. White, J. E. Champine, E. J. P. Philips, Y. A. Gorby and S. Goodwin: Arch Microbiology 159 (1993) 336-344.

34) J. Bader, H. Giinther, E. Schleicher, H. Simon, S. Pohl and W. Mannheim: Archives of Microbiology 125 (1980) 159-165.

35) K. P. Nevin and D. R. Lovley: Applied and Environmental Microbiology 66 (2000) 2248-2251.

36) A. Schwiertz, G. L. Hold, S. H. Duncan, B. Gruhl, M. D. Collins, P. A. Lawson, H. J. Flint and M. Blaut: Systematic and Applied Microbiology 25 (2002) 46-51.

37) A. Niggemyer, S. Spring, E. Stackebrandt and R. F. Rosenzweig: Applied and Environmental Microbiology 67 (2001) 5568-5580.

38) F. Barbut, M. Delmee, J. S. Brazier, J. C. Petit, I. R. Poxton, M. Rupnik, V. Lalande, C. Schneider, P. Mastrantonio, R. Alonso, E. Kuijper and M. Tvede: Clin Microbiol Infect. 9 (2003) 989-996. 